\title{
A természet közelségének jelentősége a 21. századi gyermekek fejlődésében
}

\author{
Herbert Renz-Polster \& Gerald Hüther Vissza a gyökerekhez - Így fejlődnek \\ „ezek a mai gyerekek”
}

Budapest: Ursus Libris, 2017, p. 240

ISBN 978-963-971-89-75

\section{Hill Katalin}

Eötvös Loránd Tudományegyetem Tanitó- és Óvóképzö Kar, Természettudományi Tanszék

Az ember természethez való viszonya nagyon megváltozott. A folyamat hol szép lassan, észrevétlenül, hol gyorsabban, ugrásszerủen (például ipari forradalom) zajlott, és zajlik a jelenben is. Volt idő, amikor még féltük a természetet, majd egyre jobban elkezdtünk élni vele, mígnem eljutottunk oda, hogy feléljük, uraljuk. Olyan szemmel tekintünk rá, hogy mit tudunk belőle hasznosítani. Hűen tükrözi szemléletmódunkat az erre kialakult szakkifejezés: „ökoszisztéma szolgáltatás”. A természeti környezetünk tele van felelőtlen, nem is feltétlenül tudatos magatartásunk okozta sérülésekkel (Ferenc pápa, 2015, p. 8). Mivel mindannyian szerves része vagyunk a természetnek, ezért John Donne gondolatait követve (Donne, 1839) például egy esőerdő pusztításakor vagy egy faj kihalásakor nem csak a közvetlenül érintett élőhelyekért, élőlényekért, emberekért, hanem mindenkiért kondul a harang...

Alapvetően nem a természeti kincsek használatával, hanem a túlhasználattal van a baj. Vajon milyen belső mozgatórugó állhat ennek hátterében? Az emberi természet kiolthatatlan vágya a növekedés, fejlödés. A probléma az, hogy a növekedés fókuszába az anyagi gyarapodás került, ami soha meg nem álló növekvő ütemű termelést, fogyasztást indukál. Ez a bolygó kifosztásához vezet, ám az emberi lelket sosem lesz alkalmas megelégíteni. Szükség van a társadalmi nézőpontváltozásra (Havas \& Varga, 2006) és a növekedés fókuszába a fogyasztás helyett mást, például kulturális, erkölcsi, kapcsolati növekedést helyezni.

Fontos tehát érzékelnünk, milyen nagy szükség van saját szemléletünk módosítására. Emellett pedig komoly feladat és kihívás, hogy pedagógusként a gyerekeknek egyrészt teret adjunk, másrészt támogató jobbot nyújtsunk abban, hogy a természeti környezetét szerető, érte felelősséget vállaló szemlélete alakulhasson ki. 
A fent említett természet - ember kapcsolat megváltozása ellenére is ösztönös kapcsolatban vagyunk, maradtunk a természettel. Ez a zsigeri kapcsolódás minden sejtünkbe írva van, legfeljebb elhalkult, a hangosabb ingerek elnyomják a hangját. Erről a kapcsolatról, és természet iránti vágyról tesz említést Ferenc pápa (2015) Laudati Si' enciklikájában, miközben az emberiséget ökológiai megtérésre hívja. Erről ír nagyszerü írónk, Fekete István, akinek regényei többségének fő motívuma maga a természet, és minden sorából érezhető, ahogy teljes lényét áthatja a természettel való egység, az iránta érzett szeretet. Bármilyen szakterületre tévedünk, mindenhol eljutunk arra a következtetésre, hogy a természet iránti nyitottság az emberlét lényegét képezi. Kifejlődőben van a pszichológia egy új irányzata, az ökopszichológia, melynek egyik fó célja, hogy segítsen az embereknek hazatalálni a természethez.

A természettel való elemi kötődésről ír Gerald Hüther és Herbert RenzPolster is a Vissza a gyökerekhez című könyvében, melyről az alábbiakban részletesebben olvashatunk. Neurobiológiai, pedagógiai, pszichológiai aspektusból egyaránt megvilágítja - és egyben nagy segítséget nyújt abban, hogy pedagógiai szempontból is megérthessük -, miért játszik annyira fontos szerepet a gyermekek fejlődésében a természet. A könyv bárki számára - pedagógusok számára különösen - igazi csemege, könnyen emészthető stílusban, mégis kiforrott szakmaisággal bontja ki, hogyan tudjuk visszaadni a gyermekeknek a természetben rejlő gazdagságot, illetve nyithatunk teret arra, hogy kapcsolódni tudjon hozzá. Renz-Polster és Hüther megfogalmazásában:

„Az, hogy mennyire értékeljük a természetet, annak függvénye, hogy milyenek voltak a természetélményeink. A természetélményekkel kapcsolatban nem lehet célokat felállítani. A természet elemi ösztönzést jelent a gyermeki fejlődésben - ennyi.” (Renz-Polster \& Hüther, 2017, p. 210).

Miért annyira fontos a gyermek fejlődése szempontjából a természet? A gyermekek számára a természet egy testre szabott tanulóterep, ahol kompetenciáikat saját tapasztalati úton fejlesztik ki magukban. Hüther és RenzPolster négy alapkompetencia fejlődését fejtik ki: kötődés, közvetlenség, szabadság és ellenálló képesség.

A természethez való kötődés formálódik, amikor a gyermek kapcsolatba kerül az élő és élettelen természeti elemekkel, például fákkal, madarakkal, kövekkel, illatokkal, hőmérséklettel. A kötődés élményeként pedig úgy érzi, hozzá tartozik például a fához, a fa pedig őhozzá. Ennek kialakulása alapvetően befolyásolja abban, hogyan fog dönteni természeti értékeket érintő kérdésekben.

A közvetlenség kompetenciája fejlődik, amikor a természetben az érzékszerveiket gyerekre szabott (megfelelő mennyiségü, mértékü, és komplexitású) ingerek érik (például a szemüket a levelek finom mozgásának fény-árnyék játéka). Ez különösen fontos az erőteljesen virtualizálódó világban, ahonnan 
kevésbé gazdag, ámde annál erőteljesebb inger zúdul rájuk. Az érzékszerveket ért gazdag ingerforrások megtapasztalásával saját maguk tudatosítása is elkezdődik. A természetnek kreativitást fejlesztő potenciálja van. A gyerekeknek szükségük van arra, hogy a „strukturálatlan” környezetben szabadon kezükbe vegyék a tervezést, szervezzék saját tanulásukat, kihívások elé állítsák magukat, és megtapasztalják, hogy hatást gyakorolhatnak a természetre, mintegy magukba szívva annak törvényszerüségeit. Kreatívabbá, motiváltabbá válnak, maguk szerzik be, találják ki a játékaikat.

A szabadság nem megy az egészséges korlátok rovására, hiszen maga a természet állítja fel a korlátokat, melyeket a gyermekek kénytelenek érzékelni, alkalmazkodni. Az önálló tapasztalat szerzése segíti önkontrolljuk lépésről lépésre történő kifejlődését. Meg kell küzdeniük a természet korlátaival, ami saját tapasztalat, és nem külső személyek szabályozó, kontrolláló hatása, és ez végső soron növeli ellenálló képességüket, bátrabbá, magabiztosabbá teszi őket.

A szerzőpáros a virtuális világ, médiatartalmak gyermekekre gyakorolt hatása terén is érdekes utazásra hívja az olvasókat. Vajon áldás, vagy átok a gyermekek számára az internet? Kinek, mikor, milyen körülmények között ártalmas vagy hasznos? Anélkül, hogy felmentené a különböző médiatartalmakat, vagy akár ítéletet mondana felettük, közérthetően megfogalmazva elemzi, hogyan hatnak a gyermekek neurobiológiai és pszichoszociális fejlődésére. Összehasonlítja a természetből, illetve az internet világából érkező ingerek gyermekekre gyakorolt, fejlődést befolyásoló hatásait. Rámutat arra, hogy bizonyos aggályok nagyon is megalapozottak, ilyen például a sekélyes tartalom, a kapcsolat nélküli fogyasztás veszélye, vagy a gyermek agyát érő túlzott dopamin-koncentráció. Egyes fejlődési problémák esetén viszont (például szocializációs folyamatok zavara) a baj forrását más tényezőkben (például a kapcsolati, kötődési háttérben) látja, melyet nem előállít, hanem felerősít a médiafogyasztás. Arra is kitér, véleménye szerint mikor, milyen körülmények között tud építő, fejlesztő hatást kifejteni a gyermekekre a virtuális világ.

A szerzők felteszik a kérdést: Vajon mire van szüksége a gyerekeknek? Kontrollált pedagógiai irányításra, vagy szabad felfedezésre, játékra? A kérdések valószínủleg sok pedagógusban motoszkálnak. Tény, hogy manapság a gyermekek idejük igen nagy részét töltik vezetett, szervezett pedagógiai környezetben, és kevés idejük marad az önszerveződő szabad játékra, tanulásra. A szerzőpáros gondolatébresztő felvetései segítenek megérteni a gyermekek mozgatórugóit, és támogatnak abban, hogy pedagógusként könnyebben megtaláljuk az egyensúlyt a didaktikus pedagógia vezetés és a szabad, kötetlen önszervező tanulás, a spontán alakuló képességfejlődés között. Mind a kettő nagyon fontos és szükséges, így a feladat szép kihívás. Bármelyik irányt képviseljük is adott helyzetben, célunk mindig ugyanaz: a gyermekek támogatása, hogy saját élményeikre alapozva megismerhessék, megszerethessék a természetet, így hozzájárulhatunk a természetet megbecsülő, érte aktívan küzdő pozitív attitüdjük formálódásához. 


\section{Irodalom}

Done, J. (1839). Devotions Upon Emergent Occasions Meditation XVII. In Alford, H. (Ed), The Works of John Donne. vol III. (pp. 574-575), John W. Parker.

Renz-Polster, H. \& Hüther, G. (2017). Vissza a gyökerekhez - Így fejlödnek „ezek a mai gyerekek". Ursus Libris.

Havas, P. \& Varga, A. (2006). A környezeti neveléstől a fenntarthatóság pedagógiai gyakorlata felé. In Varga, A. (Ed.), Tanulás a fenntarthatóságért (pp. 49-72). OKI.

Ferenc pápa (2015). Laudato si. Áldott légy kezdetü enciklikája közös otthonunk gondozásáról. Szent István Társulat.

Hill Katalin: https://orcid.org/0000-0002-8745-0332 